\title{
Oligoprenyl-curcumanes and other new aromatic isoprenoids from the 1.64 billion year old Barney Creek Formation
}

\author{
Jochen J. Brocks ${ }^{\mathrm{a}, *}$, Tanja Bosak ${ }^{\mathrm{b}}$, Ann Pearson ${ }^{\mathrm{c}}$ \\ ${ }^{a}$ The Research School of Earth Sciences and Centre for Macroevolution and Macroecology, The Australian National University, Canberra ACT 0200, Australia \\ ${ }^{\mathrm{b}}$ Department of Earth, Atmospheric and Planetary Sciences, Massachusetts Institute of Technology, Cambridge MA 02139, USA \\ ${ }^{\mathrm{c}}$ Department of Earth and Planetary Sciences, Harvard University, Cambridge MA 02138, USA
}

\section{A R T I C L E I N F O}

\section{Article history:}

Received 5 December 2008

Received in revised form 27 March 2009

Accepted 16 April 2009

Available online 22 April 2009

\begin{abstract}
A B S T R A C T
Carbonaceous dolomites and shales of the 1.64 billion years (Ga) old Barney Creek Formation (BCF), McArthur Basin, northern Australia contain the oldest, clearly indigenous biomarkers. We describe three new series of regularly branched aryl isoprenoids with base ions at $m / z 119,161$ and 175 . The $m / z 119$ compounds were identified as a complete series of $C_{15}-C_{40}$ oligoprenyl-perhydro-ar-curcumenes (oligoprenyl-curcumanes). Their likely biogenic precursors are oligoprenyl- $\beta$-curcumenes that occur in a wide range of bacterial phyla.
\end{abstract}

(c) 2009 Elsevier Ltd. All rights reserved.

\section{Introduction}

According to a hypothesis by Canfield (1998), the deep oceans did not become widely oxygenated with the disappearance of banded iron formations $\sim 1.8 \mathrm{Ga}$ ago, but instead remained largely anoxic and at least partially sulfidic during the 'mid-Proterozoic' interval $\sim 1.8-0.8 \mathrm{Ga}$ ago. When euxinic conditions rose into the photic zone of the marine water column, the oceans would have offered a vast habitat for the growth of green and purple sulfur bacteria. In previous publications, we tested the assumption of such a mid-Proterozoic 'age of phototrophic sulfur bacteria' by examining biomarkers in the 1.64 Ga Barney Creek Formation (BCF) in the McArthur Group of northern Australia (Brocks et al., 2005; Brocks and Schaeffer, 2008). Extracts of carbonaceous dolomites from the upper BCF yielded 22 different intact $\mathrm{C}_{40}$ carotenoid derivatives including lycopane, $\beta$-carotane, $\gamma$-carotane, renieratane, renierapurpurane, isorenieratane, $\beta$-isorenieratane and $\beta$-renierapurpurane, and aromatic carotenoid derivatives with indanyl, biphenyl and 9,10-dihydrophenanthrene end groups (Brocks and Schaeffer, 2008). Consistent with the prediction of prevailing euxinic conditions, the two most abundant hydrocarbons were the aromatic carotenoid derivatives chlorobactane and okenane, interpreted as biomarkers for green sulfur bacteria (Chlorobiaceae) and planktonic purple sulfur bacteria (Chromatiaceae), respectively. The bitumens also contain abundant $3 \beta$-methyl hopanes and triaromatic 4-methyl cholesteroids, documenting the activity of type-I methanotrophic bacteria (Brocks et al., 2005). In contrast, diagnostic eukaryotic steroids were below detection limits, consistent with the prediction of Anbar and Knoll (2002) that, beyond

\footnotetext{
* Corresponding author. Tel.: +6126125 7946.

E-mail address: jochen.brocks@anu.edu.au (J.J. Brocks).
}

shallow shelf environments, algae played an insignificant role in the nutrient-limited environments of mid-Proterozoic marine basins. Here, we describe the distribution, structures and possible significance of three series of regularly branched aromatic isoprenoids that also occur in the BCF.

\section{Geology and methods}

\subsection{Barney Creek Formation (BCF)}

The geology of the $1640 \pm 3$ Ma (Page and Sweet, 1998) BCF, McArthur Group has been summarized by Brocks and Schaeffer (2008). Briefly, it was deposited in the Batten Fault Zone, a north-south trending intracratonic rift basin that extends over an area of $\sim 25,000 \mathrm{~km}^{2}$. It is regarded as a marine succession that accumulated in a quiet, sub-wave base environment (Bull, 1998; Jackson et al., 2000; Shen et al., 2002). A highly variable depositional thickness suggests a complex bathymetry and variable water depth. The basin shallows out towards the western and southern margins, is bounded by an anticline to the north and was likely connected to the ocean to the north-east or east.

\subsection{Samples}

The 38 samples in this study come from the upper BCF from the southern end of the Batten Fault Zone (drill cores GR3, 5, 7, 8 and 10 ). They predominantly represent thinly bedded or planar laminated, dolomitic, carbonaceous and pyritic siltstones and shales. The dolomitic facies typically contain $0.2-2 \%$ organic carbon, locally up to 7\% (Powell et al., 1987). The samples, their lithology and bulk parameters are described in more detail by Brocks and Schaeffer (2008). 


\subsection{Sample preparation and analysis}

Sample processing, extraction and gas chromatography-mass spectrometry (GC-MS) analysis were described by Brocks and Schaeffer (2008) and the syngeneity of the biomarkers was discussed by Brocks et al. (2008). Due to the presence of a large unresolved complex mixture (Fig. 1), it was not possible to determine the carbon isotopic composition of individual aromatic isoprenoids.

\subsection{Preparation of tetraprenyl-curcumane reference standard}

Tetraprenyl-ar-curcumene Id was obtained from spores of a pure culture of Bacillus subtilis and isolated using preparative capillary GC as described by Bosak et al. (2008) and Kontnik et al. (2008). Tetraprenyl-curcumane IId was prepared via catalytic hydrogenation of tetraprenyl-ar-curcumene on Pd/C in heptane $(2 \mathrm{~h})$. Tetraprenylcurcumane IId was identified in bitumen from the BCF by comparison of mass spectra with the $B$. subtilis reference standard and by GC-MS coinjection experiments with a DB-5 column $(60 \mathrm{~m})$ using conditions described by Brocks and Schaeffer (2008).

\section{Results}

\subsection{Regular acyclic isoprenoids}

Regular acyclic isoprenoids with 15-20 carbons are abundant in the alkane fractions from the upper section of the BCF in the Glyde
River region and are likely mostly derived from (bacterio)chlorophylls. Regular acyclic isoprenoids with 21-25 carbons are abundant in some samples (Fig. 4A in Brocks and Schaeffer, 2008). These biomarkers have been attributed to archaea, particularly halophiles (Grice et al., 1998), although there is no geological reason to invoke halophiles in local Barney Creek environments. Regular isoprenoids with $>25$ carbons were not found.

\subsubsection{The $m / z 119$ series}

While carotenoid derivatives are the most abundant group of aromatic hydrocarbons, the second most abundant is a series of monoaromatic isoprenoids with $m / z 119$ base ion (filled circles, Fig. 1C). The series has the formula $\mathrm{C}_{n} \mathrm{H}_{2 n-6}(n=14-40)$, representing hydrocarbons with one aromatic ring. The apparent absence, or particularly low concentration, of pseudohomologues with 13,18 , 23 and 28 carbons (Fig. 1C) is consistent with the branching pattern of regular isoprenoids, but inconsistent with the branching order of carotenoids (central tail-tail link) and biphytanes (central head-head link). The $m / z 119$ base ion is consistent with a phenyl group with a variety of different alkyl substitution patterns, including III with one aromatic ring located in the middle of an alkyl chain, and IVa and Va where the phenyl group is terminal. Structure III can be ruled out as the spectra (Fig. 2A and B) of the $m / z$ 119 series lack fragment ions that represent the loss of one of the two alkyl side chains (cf. spectra in Sinninghe Damste et al., 1991 and Adam et al., 2006). Thus, the $m / z 119$ series has the general structure of aryl isoprenoids IV or $\mathbf{V}$ with two or one additional carbons at the terminal aromatic ring, respectively. Assuming that

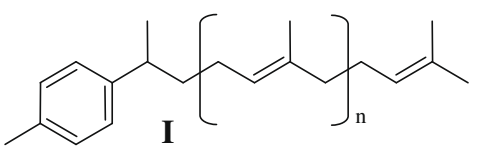

(a) $\mathrm{n}=0 \quad\left(\mathrm{C}_{15}\right.$, ar-curcumene $)$

(b) $\mathrm{n}=1 \quad\left(\mathrm{C}_{20}\right.$, monoprenyl-ar-curcumene $)$

(c) $\mathrm{n}=2 \quad\left(\mathrm{C}_{30}\right.$, triprenyl-ar-curcumene $)$

(d) $\mathrm{n}=3 \quad\left(\mathrm{C}_{35}\right.$, tetraprenyl-ar-curcumene $)$<smiles>CCC(CC)(CCC(C)CC(C)C)CC(C)C(C)c1ccc(C)cc1</smiles>

(a) $\mathrm{n}=0 \quad\left(\mathrm{C}_{15}\right.$, curcumane $)$

(b) $\mathrm{n}=1 \quad\left(\mathrm{C}_{20}\right.$, monoprenyl-curcumane $)$

(c) $\mathrm{n}=2 \quad\left(\mathrm{C}_{30}\right.$, triprenyl-curcumane $)$

(d) $\mathrm{n}=3 \quad\left(\mathrm{C}_{35}\right.$, tetraprenyl-curcumane $)$

(e) $\mathrm{n}=4 \quad\left(\mathrm{C}_{40}\right.$, pentaprenyl-curcumane $)$

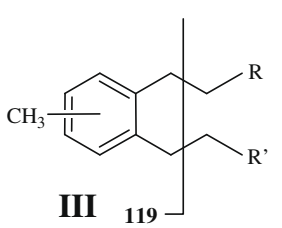

III 119

(a) $\mathrm{n}=2$ for $m / z 119$ Da series

(b) $\mathrm{n}=5$ for $m / z 161$ Da series

(c) $\mathrm{n}=6$ for $m / z 175$ Da series

(a) $\mathrm{n}=1$ for $m / z$ 119 Da series

(b) $\mathrm{n}=4$ for $m / z, 161$ Da series

(c) $\mathrm{n}=5$ for $\mathrm{m} / z 175 \mathrm{Da}$ series<smiles>Cc1ccc(C)c(CCC(C)(C)CCCC(C)CCCC(C)CCCC(C)C)c1</smiles><smiles>[Y1]CC(CC)(CCC(C)CC(C)(CC)CC(C)C)CC(C)C1CCC(C)CC1</smiles>

(a) $\mathrm{n}=0 \quad\left(\mathrm{C}_{15}\right.$, bisabolane $)$

(b) $\mathrm{n}=1 \quad\left(\mathrm{C}_{20}\right.$, monoprenyl-bisabolane $)$

(c) $\mathrm{n}=2 \quad\left(\mathrm{C}_{30}\right.$, triprenyl-bisabolane)

(d) $\mathrm{n}=3 \quad\left(\mathrm{C}_{35}\right.$, tetraprenyl-bisabolane $)$<smiles>[X]C(CC(C)(CC)CC(C)=CC(C)(CC)CC(C)C)C1=CCC(C)=CC1</smiles>

(a) $\mathrm{n}=0 \quad\left(\mathrm{C}_{15}, \beta\right.$-curcumene $)$

(b) $\mathrm{n}=1 \quad\left(\mathrm{C}_{20}\right.$, monoprenyl- $\beta$-curcumene $)$

(c) $\mathrm{n}=2 \quad\left(\mathrm{C}_{30}\right.$, triprenyl- $\beta$-curcumene $)$

(d) $\mathrm{n}=3 \quad\left(\mathrm{C}_{35}\right.$, tetraprenyl- $\beta$-curcumene $)$ 


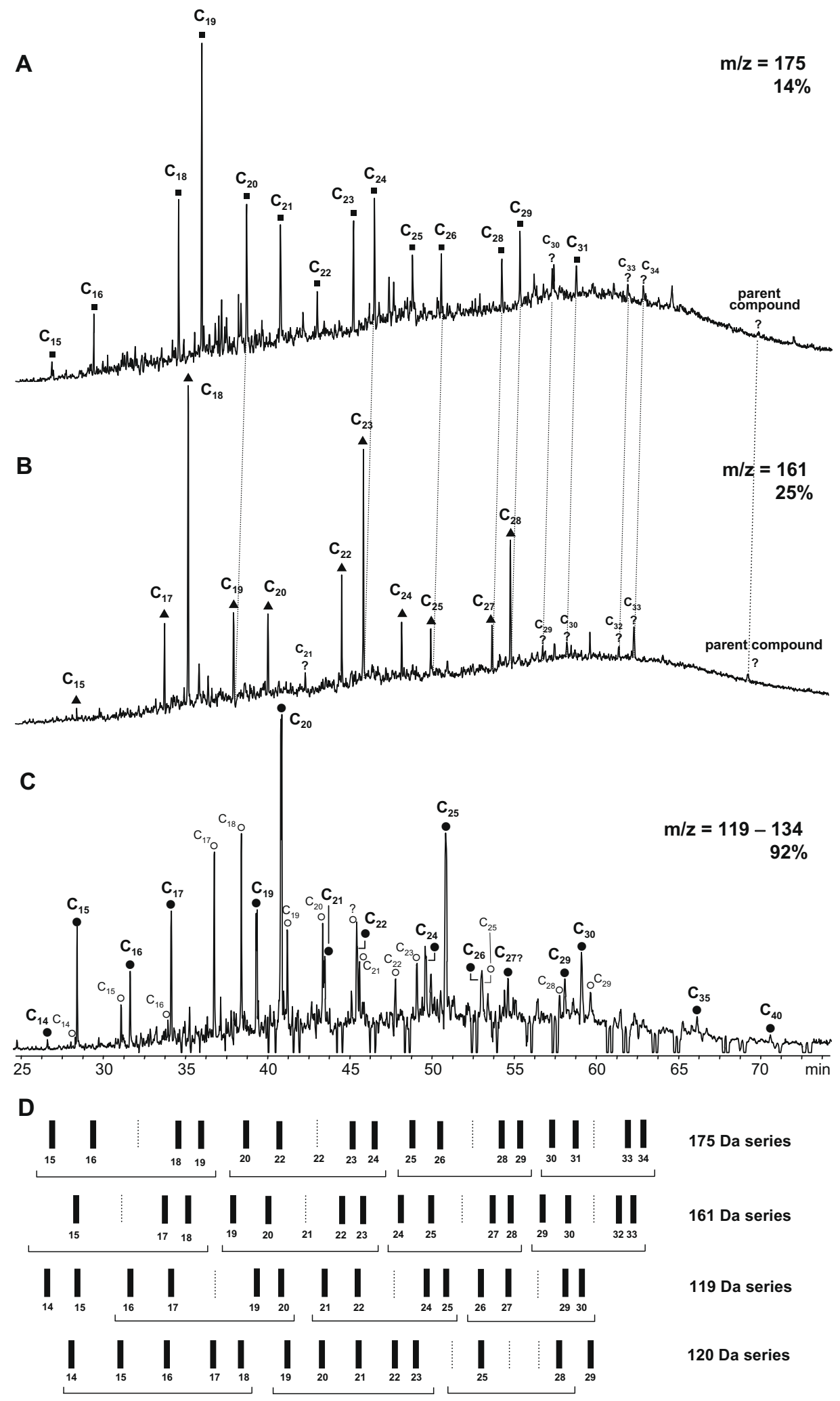

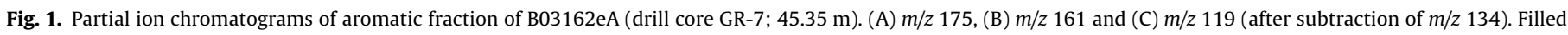

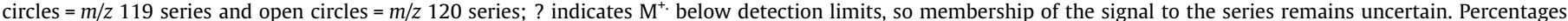

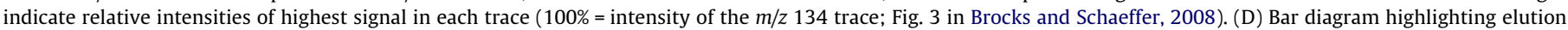

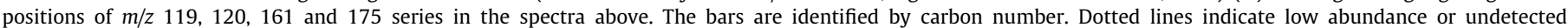
pseudohomologues.

the biological precursor of the $m / z 119$ series is a regular isoprenoid, then Ile appears to be the only valid structure for the $C_{40}$ parent compound that may form without rearrangement or loss of carbons. This interpretation is supported by the spectrum of the $\mathrm{C}_{15}$ pseudohomologue (Fig. 2A), which is identical to that of curcumane IIa in Ellis et al. (1995). The identity of the series was con- 

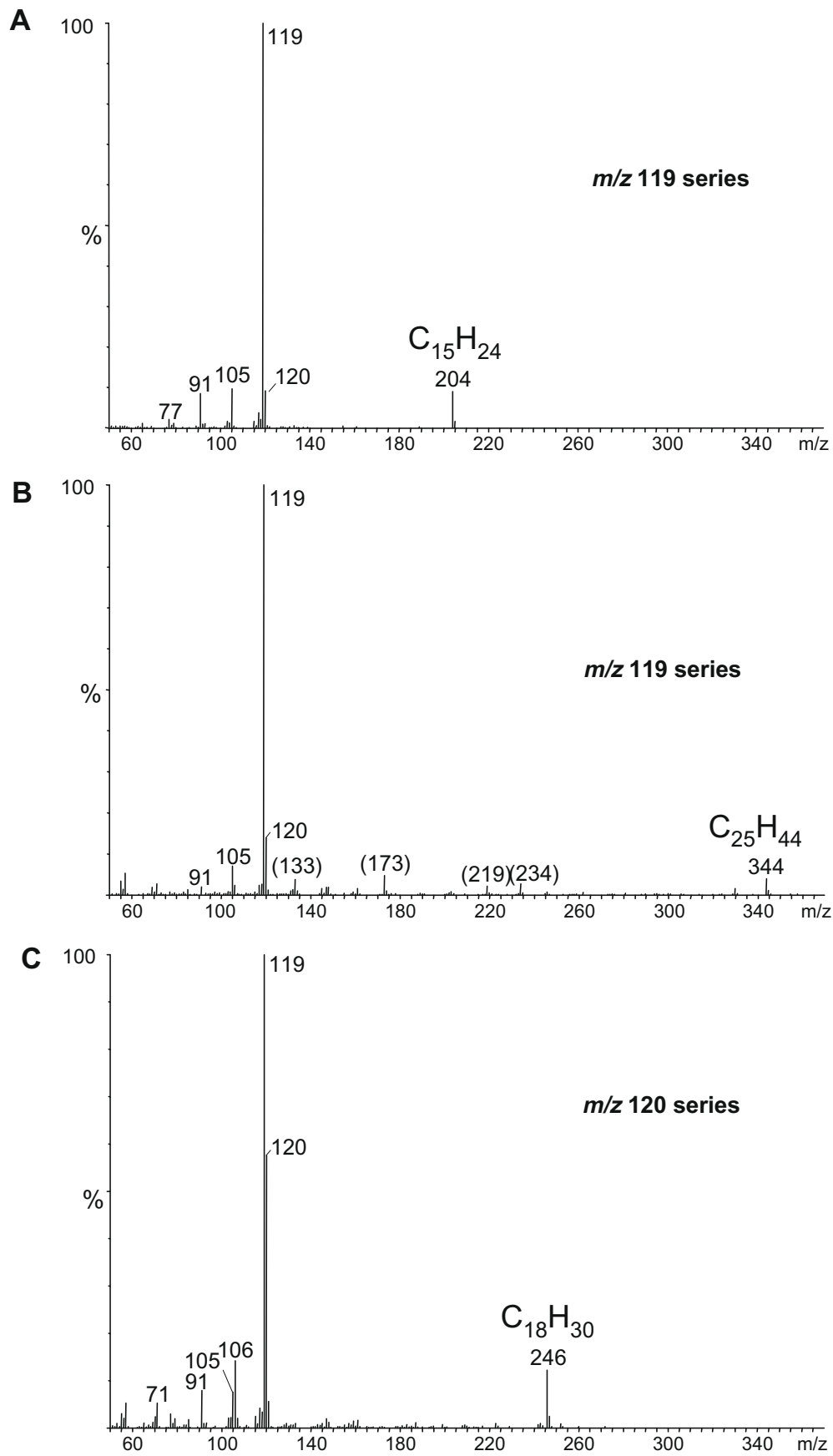

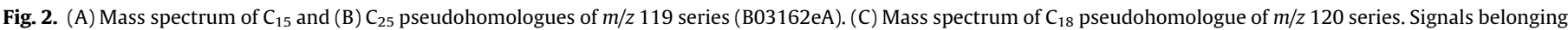
demonstratively to the series are labelled with a mass number. Fragment ions in parentheses belong to coeluting compounds.

firmed by comparison of mass spectra and co-elution experiments with a tetraprenyl-curcumane IId standard.

Isoperhydro-ar-curcumenes, that possess a meta rather than para methyl, and elute significantly earlier (Bastow et al., 1997), were not detected. According to Bastow et al. (1998), isoperhydro-ar-curcumenes form via acid catalyzed isomerization of curcumanes at relatively low maturity. Thus, the low abundance or absence of meta isomers may reflect the basic nature of the carbonate host rock.

An outstanding characteristic of the $m / z 119$ series is the high relative intensity of pseudohomologues with $15,20,25,30,35$ and 40 carbons (Fig. 1C). This would not be expected if lower pseudohomologues formed by cracking of a parent $\mathrm{C}_{40}$ compound IIe. An isoprenoid side chain breaks preferably $\alpha$ to a branching position, which would have generated predominant fragments with $14,17,19,22,24,27$, etc. carbons. Therefore, the predominance of pseudohomologues with carbon number multiples of 5 strongly suggests that the biological precursors of the $m / z 119$ series were a complete series of $\mathrm{C}_{15}-\mathrm{C}_{40}$ isoprenoids with oligoprenyl-curcumane skeletons II.

\subsubsection{The $\mathrm{m} / \mathrm{z} 120$ series}

Fig. $1 \mathrm{C}$ also reveals major signals that are not part of the $m / z 119$ series (open circles). These signals are distinguished by a more 
intense McLafferty $m / z 120$ fragment and by $m / z 106$ greater than $\mathrm{m} / z 105$ (Fig. 2C). In this series, a continuous set of compounds with 14-23 carbons was detected, as well as 25, 28 and 29 carbons. Each carbon number is represented by a single isomer. Based on the elution pattern (Fig. 1D), all the compounds appear to belong to a single structurally related series. However, as the elution positions are not equidistant, the compounds do not represent an $n$-alkyl benzene homologous series similar to those described by Sinninghe Damsté et al. (1991). Instead, the peaks occur in sets of $5\left(C_{14}-C_{18}\right.$ and $\left.C_{19}-C_{23}\right)$, where the first four signals have approximately equidistant elution times and the last is offset to a shorter elution position (Fig. 1D). Comparison with the elution pattern of the $m / z 175,161$ and 119 series reveals that this pattern is consistent with a side chain methylated at C-16 and C-21 (numbering in Fig. 1D).

Aryl isoprenoids methylated at C-16 and C-21 and with $m / z 120$ as base ion may, in principle, form via diagenetic reduction of dimethylated quinones and chromans. Compounds of this type with 28 carbons (VI and VII) were described by Sinninghe Damsté et al. (1988). However, the $m / z 120$ series in the BCF is different for two reasons. Firstly, the phytanyl benzenes VI and VII possess a methyl in the $\gamma$ position of the side chain, causing a McLafferty fragment $(m / z 120 / 119 \approx 3$; Sinninghe Damsté et al., 1988) that is significantly stronger than in the BCF series $(m / z \quad 120 /$ $119 \approx 0.5-0.6$ ). Secondly, based on branching positions, pseudohomologues $C_{16}$ and $C_{21}$ should have low signal intensity (as seen for $C_{18}, C_{23}$ and $C_{28}$ in the $m / z 119$ series; Fig. 1D). However, only $C_{16}$ is low but not $C_{21}$ (Fig. 1C). Thus, the $m / z 120$ series does not represent the degradation products of quinones and chromans and the nature of the compounds remains obscure.

It is particularly intriguing that all pseudohomologues of the $m / z 120$ series between $C_{14}$ and $C_{23}$ are present despite the fact that this is inconsistent with the irregular elution order that implies a branched side chain. Moreover, the chromatographic signals do not split into doublets or become significantly broader with increasing carbon number, as usually observed for side chains that exhibit multiple racemized branching positions (cf. the increasing width of chromatographic signals in the $m / z 119$ series, Fig. 1C). Furthermore, although the $C_{25}, C_{28}$ and $C_{29}$ pseudohomologues are in predicted elution positions (Fig. 1D), pseudohomologues $\mathrm{C}_{24}, \mathrm{C}_{26}$ and $\mathrm{C}_{28}$ were not detected. To determine whether the $\mathrm{m} / \mathrm{z} 120$ compounds represent one contiguous series of aromatic isoprenoids or not, it may be necessary to search for them in younger bitumens.

\subsubsection{The $m / z 161$ and 175 series}

The BCF contains two further aryl isoprenoid series with regular head-tail patterns (Fig. 1A and B). The first has $m / z 161$ as base ion, consistent with a $\mathrm{C}_{6}$ substituted phenyl ion, and molecular masses consistent with $\mathrm{C}_{n} \mathrm{H}_{2 n-6}$ ( $n=15-28$ and possibly to 38 or 39 ). The $\mathrm{M}^{+}$. has a relative intensity of $12 \%$ for the $C_{17}$ pseudohomologue, but the intensity decreases with increasing molecular mass $(4 \%$ for $C_{28}$ ). The $m / z 162$ McLafferty fragment has a relatively low intensity of $10-15 \%$ relative to the base ion. The presence of other fragment ions was difficult to determine because of low signal to noise ratio. However, a $\mathrm{m} / \mathrm{z} 133$ fragment appears to be present in all members of the series at $20-50 \%$ intensity, as well as a $m / z$ 147 fragment at $10-20 \%$. Fragment ions $>m / z 161$ could not be observed. The second series has $m / z 175$ as base ion, consistent with a $\mathrm{C}_{7}$-substituted phenyl ion and $\mathrm{C}_{n} \mathrm{H}_{2 n-6}(n=16-31$ and possibly to 39 or 40 ). The relative intensities of the $\mathrm{M}^{+}$. and the $\mathrm{m} / z 176$ McLafferty ion are comparable to those from the $\mathrm{m} / \mathrm{z} 161$ series. Because of low signal to noise ratio, it was not possible to confirm the presence of weaker fragment ions.

The $m / z 161$ and 175 series are clearly related to the $m / z 119$ series. All three have a pseudohomologue distribution, indicating a side chain with a regular isoprenoid branching pattern (Fig. 1D). The general structure for the series appears to be IVa-c or Va-c, distinguished only by the number of alkyl substituents on the aromatic ring. As discussed above, the $m / z 119$ series probably had a set of biological precursors with 15, 20, 25, 35 and 40 carbons. Similarly, the $m / z 175$ series shows particularly high concentrations of pseudohomologues with 19, 24, 29, 34 (and 39 ?) carbons, suggesting that they were generated from biological $\mathrm{C}_{5 n}$ precursors after loss of one carbon at the open end of the isoprenoid chain. The same phenomenon is observed for the $m / z$ 161 series for pseudohomologues with 18, 23, 28, 33 (and 38?) carbons and it appears likely that it formed from the same precursors as the $m / z 175$ series via loss of a second carbon at the aromatic terminus. The only structure for the $m / z 175$ series that can be generated by diagenetic cyclization and aromatization of a regular acyclic isoprenoid without shifting carbons is VIII. However, biological lipids with the carbon skeleton of VIII are unknown, and we speculate that the biogenic precursors of both series possessed a biosynthetically modified, i.e. non-isoprenoid, head group (similar, in principle, to the cyclic moieties of chromans and quinones). The $m / z 161$ and 175 series both occur in similar concentrations in the BCF and potentially originated from the same biogenic precursor through different diagenetic reactions. The loss of one carbon in the side chain, leading to the $m / z 175$ series and the loss of a second at the aromatic ring, leading to the $m / z 161$ series, may indicate that these positions carried functional groups that were lost during diagenesis (e.g. by oxidation and decarboxylation).

\subsubsection{Other regular isoprenoid series}

The $m / z 91$ and 105 chromatograms are strongly dominated by $n$-alkyl benzenes, but monoaromatic isoprenoids with $m / z$ and 105 base ions were not detected. Similarly, no monoaromatic isoprenoids were detected in the $m / z$ 147, 189, 203 and 217 chromatograms.

\section{Discussion}

The oligoprenyl-curcumanes II of the BCF may, in principle, have formed by diagenetic alteration of acyclic isoprenoids. Suitable acyclic precursors are widespread in the biosphere. Therefore, oligoprenyl-curcumanes should be relatively common in bitumens of any age. However, curcumane Ila is rare (see below) and oligoprenyl-curcumanes IIc-e with more than 20 carbons have never been reported until now. Moreover, in the BCF, acyclic regular isoprenoids with 30-40 carbons were not detected although oligoprenyl-curcumanes II with 30-40 carbons are abundant. Thus, diagenetic conversion of acyclic precursors to oligoprenyl-curcumanes II is not probable, and direct biological precursors with oligoprenyl-curcumane II skeletons are more likely.

Monocyclic sesquiterpenoids $\left(C_{15}\right)$ with the bisabolane IX and curcumane II skeletons have been isolated from a red alga (Ellis et al., 1995) and a marine sponge (Butler et al., 1991) and occur abundantly in the essential oils of higher plants. The name curcumene is derived from Curcuma, a plant genus that includes turmeric. Consistent with a plant source, fossil curcumane IIa is relatively abundant in coals and crude oils that contain high relative concentrations of other plant biomarkers (Ellis et al., 1995). A predominant plant origin is also supported by the presence of curcumane Ila in amber (Czechowski et al., 1996; Grimalt et al., 1988; Yamamoto et al., 2006) and its apparent absence from Cambrian to Devonian sediments (Ellis et al., 1995).

Monoprenyl-curcumane $\left(\mathrm{C}_{20}\right)$ IIb is rare in the geological record. The only report appears to be from a middle Albian coal in Spain (Gorchs et al., 2003), but the data were insufficient for reliable identification. The saturated counterpart of monoprenyl- 
curcumane IIb, monoprenyl-bisabolane IXb, was tentatively assigned in very high relative abundance in lower Albian black shales deposited during oceanic anoxic event (OAE) 1b in southeastern France (Vink et al., 1998) and the North Atlantic Ocean off the coast of Florida (Kuypers et al., 2002). The carbon isotopic composition of monoprenyl-bisabolane IXb from OAE $1 \mathrm{~b}$ in the North Atlantic Ocean $\left(\delta^{13} \mathrm{C} \approx-15 \%\right.$ ) was similar to that of diagnostic archaeal isoprenoids, but was offset from that of algal biomarkers by $>10 \%$. Consistent with the isotopic composition, Kuypers et al. (2002) suggested an archaeal source for monoprenyl-bisabolane IVb. The authors also noted that the compound had never been reported outside the OAE $1 \mathrm{~b}$ black shale interval.

To our knowledge, oligoprenyl-curcumanes II (and oligoprenylbisabolanes IX) with more than 20 carbons have not been reported from the geological record and are currently unique to the BCF. However, potential biogenic precursors for the $C_{30}$ IIc and $C_{35}$ IId pseudohomologues are known. Heptaprenylcycline possesses a tetraprenyl-bisabolane IXd skeleton with one unsaturation in the cyclohexyl moiety and was observed in three nonpathogenic species of Mycobacterium. It might play a role in the temperature adaptation of mycobacterial cell membranes (Sato et al., 2008). Tetraprenyl-ar-curcumene Id and tetraprenyl- $\beta$-curcumene Xd were detected (Böröczky et al., 2006) in cultivated isolates from four major bacterial groups from the North Sea, Actinobacteria (Brevibacterium, Clavibacter, Microbacterium), $\alpha$-Proteobacteria (Brevundimonas, Jannaschia, Oceanibulbus, Roseobacter, Sulfitobacter), $\gamma$-Proteobacteria (Pseudoalteromonas, Vibrio, Halomonas, Marinomonas) and Bacteroidetes (Cyclobacterium, Cytophaga, Flavobacterium). The extracts also contained smaller concentrations of triprenyl-ar-curcumene Ic and triprenyl- $\beta$-curcumene $\mathbf{X c}$. Tetraprenyl-ar-curcumene Id and tetraprenyl- $\beta$-curcumene $\mathbf{X d}$ were recently also isolated from $B$. subtilis (Firmicutes), along with polycyclic derivatives in which the tetraprenyl side chain has been modified to form scalarane (Bosak et al., 2008; Kontnik et al., 2008).

In B. subtilis, tetraprenyl- $\beta$-curcumene $\mathbf{X d}$ is probably biosynthesized from all-trans heptaprenyl pyrophosphate (Takahashi et al., 1980). Kontnik et al. (2008) suggest that cyclization occurs at the pyrophosphate terminus and directly yields the cyclohexadiene end group of tetraprenyl- $\beta$-curcumene Xd. The dehydrogenation of the cyclohexadiene end group to the aromatic moiety of tetraprenyl-ar-curcumene Id is possibly an abiogenic process, although biological oxidation is also possible. Böröczky et al. (2006) observed that tetraprenyl- $\beta$-curcumene $\mathbf{X d}$ spontaneously oxidizes to tetraprenyl-ar-curcumene Id during isolation of lipids from bacterial cultures. They speculate that the fast oxidation may be related to the physiological function of $\beta$-curcumenes $\mathbf{X}$ in bacteria. In contrast, the lipid extracts of sporulating $B$. subtilis cells and spores contain similar amounts of tetraprenyl-ar-curcumenes Id and tetraprenyl$\beta$-curcumenes Xd (Bosak et al., 2008) and the ratio of the two compounds does not change rapidly under their experimental conditions. However, the abundance of polycyclic sporulenes with an aromatic end group in the same extracts is much higher than that of sporulenes containing a cyclohexadiene end group (Bosak et al., 2008; Kontnik et al., 2008), suggesting that the redox activities of sporulenes and tetraprenyl curcumenes differ. Given that sporulenes protect spores against oxidative stress (Bosak et al., 2008), either by reducing the permeability of cell membranes to molecular oxygen and/or by scavenging reactive oxygen species with the cyclohexadiene head group (Kontnik et al., 2008), linear curcumenes may have a similar physiological role. The current understanding of the microbial sources of curcumenes supports this because these molecules have only been found in aerobically grown microbes (Böröczky et al., 2006; Bosak et al., 2008; Sato et al., 2008). However, at this stage, we do not recommend interpreting fossil curcumanes as indicators for oxidative stress. Further studies of the biosynthetic path- ways leading to tetraprenyl curcumenes, their modern microbial sources and chemical properties will have to be carried out to confirm or not whether $\beta$-curcumenes $\mathbf{X}$ directly function as scavengers of reactive oxygen species and whether this is their only physiological role.

\section{Conclusions}

Bitumens from the $1.64 \mathrm{Ga}$ old Barney Creek Formation in the McArthur Basin of northern Australia contain at least three new series of regular aromatic isoprenoids. While the substitution patterns of the phenyl end groups of the series with base ions at $m / z$ 161 and 175 remain unknown, compounds with $m / z 191$ base ion were identified as a complete series of $C_{15}-C_{40}$ oligoprenyl-curcumanes II. Plausible biogenic precursors are oligoprenyl- $\beta$-curcumenes $\mathbf{X}$ that have been isolated from a broad range of bacterial phyla. Tetraprenyl-curcumenes are the likely biosynthetic precursors of bacterial sporulenes that play a role in oxidative stress response. A direct physiological function of oligoprenyl- $\beta$-curcumenes in bacteria is not known, but further physiological studies should test whether the cyclohexadiene moiety functions as a scavenger of reactive oxygen species and whether curcumanes II can be regarded as biomarkers for oxidative stress response.

\section{Acknowledgements}

The work was supported by the William F. Milton Fund of Harvard University, Geoscience Australia, the Australian Research Council (ARC), the David and Lucille Packard Foundation and the Harvard University Microbial Sciences Initiative. We thank J. Hope for technical support, Geoscience Australia and the Northern Territory Geological Survey for samples, and K. Grice and an anonymous reviewer for helpful comments.

\section{Associate Editor-P. Schaeffer}

\section{References}

Adam, P., Schaeffer, P., Albrecht, P., 2006. $C_{40}$ monoaromatic lycopane derivatives as indicators of the contribution of the alga Botryococcus braunii race $\mathrm{L}$ to the organic matter of messel oil shale (Eocene, Germany). Organic Geochemistry 37, 584-596.

Anbar, A.D., Knoll, A.H., 2002. Proterozoic ocean chemistry and evolution: a bioinorganic bridge? Science 297, 1137-1142.

Bastow, T.P., Alexander, R., Kagi, R.I., 1997. Identification and analysis of dihydro-arcurcumene enantiomers and related compounds in petroleum. Organic Geochemistry 26, 79-83.

Bastow, T.P., Alexander, R., Kagi, R.I., Sosrowidjojo, I.B., 1998. The effect of maturity and biodegradation on the enantiomeric composition of sedimentary dihydroar-curcumene and related compounds. Organic Geochemistry 29, 1297-1304.

Böröczky, K., Laatsch, H., Wagner-Döbler, I., Stritzke, K., Schulz, S., 2006. Cluster analysis as selection and dereplication tool for the identification of new natural compounds from large sample sets. Chemistry and Biodiversity 3, 622-634.

Bosak, T., Losick, R.M., Pearson, A., 2008. A polycyclic terpenoid that alleviates oxidative stress. Proceedings of the National Academy of Sciences, USA 105 6725-6729.

Brocks, J.J., Love, G.D., Summons, R.E., Knoll, A.H., Logan, G.A., Bowden, S.A., 2005 Biomarker evidence for green and purple sulphur bacteria in a stratified Paleoproterozoic sea. Nature 437, 866-870.

Brocks, J.J., Grosjean, E., Logan, G.A., 2008. Assessing biomarker syngeneity using branched alkanes with quaternary carbon (BAQCs) and other plastic contaminants. Geochimica et Cosmochimica Acta 72, 871-888.

Brocks, J.J., Schaeffer, P., 2008. Okenane, a biomarker for purple sulfur bacteria (Chromatiaceae), and other new carotenoid derivatives from the $1,640 \mathrm{Ma}$ Barney Creek Formation. Geochimica et Cosmochimica Acta 72, 1396-1414.

Bull, S.W., 1998. Sedimentology of the Palaeoproterozoic Barney Creek Formation in DDH BMR McArthur 2, southern McArthur Basin, Northern Territory. Australian Journal of Earth Sciences 45, 21-31.

Butler, M.S., Capon, R.J., Nadeson, R., Beveridge, A.A., 1991. Aromatic bisabolenes from an Australian marine sponge, Arenochalina sp. Journal of Natural Products 54, 619-623.

Canfield, D.E., 1998. A new model for Proterozoic ocean chemistry. Nature 396 450-453. 
Czechowski, F., Simoneit, B.R.T., Sachanbinski, M., Chojcan, J., Wolowiec, S., 1996. Physicochemical structural characterization of ambers from deposits in Poland Applied Geochemistry 11, 811-834.

Ellis, L., Singh, R.K., Alexander, R., Kagi, R.I., 1995. Identification and occurrence of dihydroar-curcumene in crude oils and sediments. Organic Geochemistry 23, 197-203.

Gorchs, R., Olivella, M.A., de las Heras, F.X.C., 2003. New aromatic biomarkers in sulfur-rich coal. Organic Geochemistry 34, 1627-1633.

Grice, K., Schouten, S., Nissenbaum, A., Charrach, J., Sinninghe Damsté, J.S., 1998. Isotopically heavy carbon in the $C_{21}$ to $C_{25}$ regular isoprenoids in halite-rich deposits from the Sdom Formation, Dead Sea Basin, Israel. Organic Geochemistry 28, 349-359.

Grimalt, J.O., Simoneit, B.R.T., Hatcher, P.G., Nissenbaum, A., 1988. The molecular composition of ambers. Organic Geochemistry 13, 677-690.

Jackson, M.J., Southgate, P.N., Winefield, P.R., Barnett, K., Zeilinger, I., 2000. Revised sub-division and regional correlation of the McArthur Basin succession based on NABRE's 1995-8 sequence stratigraphic studies. Australian Geological Survey Organization, Record 2000/03, Canberra.

Kontnik, R., Bosak, T., Butcher, R.A., Brocks, J.J., Losick, R., Clardy, J., Pearson, A., 2008 Sporulenes, heptaprenyl metabolites from Bacillus subtilis spores. Organic Letters 10, 3551-3554.

Kuypers, M.M.M., Blokker, P., Hopmans, E.C., Kinkel, H., Pancost, R.D., Schouten, S. Sinninghe Damsté, J.S., 2002. Archaeal remains dominate marine organic matter from the early Albian oceanic anoxic event 1b. Palaeogeography, Palaeoclimatology, Palaeoecology 185, 211-234.

Page, R.W., Sweet, I.P., 1998. Geochronology of basin phases in the western Mt Isa Inlier, and correlation with the McArthur Basin. Australian Journal of Earth Sciences 45, 219-232.
Powell, T.G., Jackson, M.J., Sweet, I.P., Crick, I.H., Boreham, C.J., Summons, R.E., 1987. Petroleum geology and geochemistry, middle Proterozoic McArthur Basin. Bureau of Mineral Resources Record 1987/48, Canberra.

Sato, T., Kigawa, A., Takagi, R., Adachi, T., Hoshino, T., 2008. Biosynthesis of a novel cyclic $\mathrm{C}_{35}$-terpene via the cyclisation of a Z-type $\mathrm{C}_{35}$-polyprenyl diphosphate obtained from a nonpathogenic Mycobacterium species. Organic and Biomolecular Chemistry 6, 3788-3794.

Shen, Y., Canfield, D.E., Knoll, A.H., 2002. Middle Proterozoic ocean chemistry: evidence from the McArthur Basin, northern Australia. American Journal of Science 302, 81-109.

Sinninghe Damsté, J.S., Kock-van Dalen, A.C., Albrecht, P., de Leeuw, J.W., 1991. Identification of long-chain 1,2-di-n-alkylbenzenes in Amposta crude oil from the Tarragona Basin, Spanish Mediterranean: implications for the origin and fate of alkylbenzenes. Geochimica et Cosmochimica Acta 55, 3677-3683.

Sinninghe Damsté, J.S., Kock-van Dalen, A.C., de Leeuw, J.W., 1988. Identification of long-chain isoprenoid alkylbenzenes in sediments and crude oils. Geochimica et Cosmochimica Acta 52, 2671-2677.

Takahashi, I., Ogura, K., Seto, S., 1980. Heptaprenyl pyrophosphate synthetase from Bacillus subtilis. Journal of Biological Chemistry 255, 4539-4543.

Vink, A., Schouten, S., Sephton, S., Sinninghe Damsté, J.S., 1998. A newly discovered norisoprenoid, 2,6,15,19-tetramethylicosane, in Cretaceous black shales. Geochimica et Cosmochimica Acta 62, 965-970.

Yamamoto, S., Otto, A., Krumbiegel, G., Simoneit, B.R.T., 2006. The natural product biomarkers in succinite, glessite and stantienite ambers from Bitterfeld, Germany. Review of Palaeobotany and Palynology 140, 27-49. 